\title{
Sex reversal and ontogeny under climate change and chemical pollution: are there interactions between the effects of elevated temperature and a xenoestrogen on early development in agile frogs? ${ }^{\text {in }}$
}

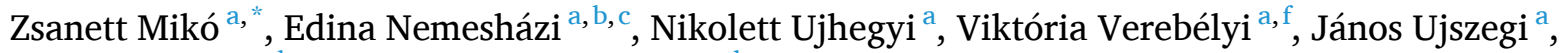 \\ Andrea Kásler $^{\text {a,d }}{ }^{\text {, Réka Bertalan }}{ }^{\mathrm{a}}$, Nóra Vili ${ }^{\mathrm{b}}$, Zoltán Gál ${ }^{\mathrm{e}}$, Orsolya I. Hoffmann ${ }^{\mathrm{e}}$, \\ Attila Hettyey ${ }^{\text {a }}$, Veronika Bókony ${ }^{\text {a,d }}$ \\ ${ }^{a}$ Lendület Evolutionary Ecology Research Group, Plant Protection Institute, Centre for Agricultural Research, Eötvös Loránd Research Network, Herman Ottó u. 15, H- \\ 1022, Budapest, Hungary \\ ${ }^{\mathrm{b}}$ Conservation Genetics Research Group, Department of Ecology Institute for Biology, University of Veterinary Medicine, Budapest, István utca 2, H-1078, Budapest, \\ Hungary \\ ${ }^{\mathrm{c}}$ Konrad Lorenz Institute of Ethology, Department of Interdisciplinary Life Sciences, University of Veterinary Medicine, Savoyenstr. 1a, A-1160, Vienna, Austria \\ ${ }^{\mathrm{d}}$ Department of Systematic Zoology and Ecology, Institute of Biology, Eötvös Loránd University, Pázmány Péter Sétány 1/c, H-1117, Budapest, Hungary \\ ${ }^{\mathrm{e}}$ Animal Biotechnology Department, Institute of Genetics and Biotechnology, Hungarian University of Agriculture and Life Science, Szent-Györgyi Albert u. 4, H-2100, \\ Gödöllö, Hungary \\ ${ }^{\mathrm{f}}$ Fish Parasitology Research Team, Veterinary Medical Research Institute, Eötvös Loránd Research Network, Hungária körút 21, H-1143, Budapest, Hungary
}

\section{A R T I C L E I N F O}

\section{Keywords:}

Estrogenic pollution

Heat stress

Sex ratio

Ectothermic vertebrates

Climate warming

\begin{abstract}
A B S T R A C T
Anthropogenic environmental change poses a special threat to species in which genetic sex determination can be overwritten by the thermal and chemical environment. Endocrine disrupting chemicals as well as extreme temperatures can induce sex reversal in such species, with potentially wide-ranging consequences for fitness, demography, population viability and evolution. Despite accumulating evidence suggesting that chemical and thermal effects may interact in ecological contexts, little is known about their combined effects on sex reversal. Here we assessed the simultaneous effects of high temperature (female-to-male sex-reversing agent) and $17 \alpha$ ethinylestradiol (EE2), a widespread xenoestrogen (male-to-female sex-reversing agent), on sexual development and fitness-related traits in agile frogs (Rana dalmatina). We exposed tadpoles to a six-days heat wave $\left(30{ }^{\circ} \mathrm{C}\right)$ and/or an ecologically relevant concentration of EE2 (30 ng/L) in one of three consecutive larval periods, and diagnosed sex reversals two months after metamorphosis using species-specific markers for genetic sexing. We found that high temperature induced female-to-male sex reversal, decreased survival, delayed metamorphosis, decreased body mass at metamorphosis, and increased the proportion of animals that had no fat bodies, while EE2 had no effect on these traits. Simultaneous exposure to heat and EE2 had non-additive effects on juvenile body mass, which were dependent on treatment timing and further complicated by a negative effect of sex reversal on body mass. These results show that environmentally relevant exposure to EE2 does not diminish the female-to-male sex-reversing effects of high temperature. Instead, our findings on growth suggest that climate change and chemical pollution may have complex consequences for individual fitness and population persistence in species with environment-sensitive sex determination.
\end{abstract}

\section{Introduction}

Our ecosystem is facing a multitude of rapid environmental changes induced by human activities, including climate change and various forms of environmental pollution. These anthropogenic environmental changes can affect the neuroendocrine, cardiorespiratory, iono- and osmoregulatory, immune and reproductive systems of wild animals influencing their growth and development especially during early life

\footnotetext{
This paper has been recommended for acceptance by Sarah Harmon.

* Corresponding author.

E-mail address: miko.zsanett@atk.hu (Z. Mikó).
} 
(Bernanke and Köhler, 2009; Burraco et al., 2020; Parmesan, 2006; Sparling et al., 2010; Whitney et al., 2016). Moreover, both climate change and environmental contaminants pose a special threat to species in which sex determination and sexual development are sensitive to environmental conditions. For example, sex determination is purely temperature-dependent in many ectothermic vertebrates, thus climate change puts such species in danger of skewed sex ratios, with potentially wide-ranging consequences from evolutionary changes in breeding systems and social behaviors (Liker et al., 2014, 2013) and reduced genetic diversity to demographic collapse (Mitchell and Janzen, 2010). Furthermore, in several species of fish, amphibians, and reptiles, sex is determined genetically but is additionally influenced by thermal or chemical stimuli experienced during early ontogeny (Eggert, 2004; Holleley et al., 2016; Ospina-Alvarez and Piferrer, 2008), which can result in sex reversal, a mismatch between genetic sex and phenotypic sex (Holleley et al., 2016; Lambert et al., 2019; Nemesházi et al., 2020). The consequences of sex reversal go beyond skewed sex ratios in these species as well, because sex-reversed individuals may have lower or higher reproductive success than conspecifics in which phenotypic sex and chromosomal sex are concordant (Holleley et al., 2016; Senior et al., 2012), and may produce sex-biased offspring which may lead to changes in demography, sex-chromosome evolution and even to extinction (Bókony et al., 2017; Nemesházi et al., 2021; Quinn et al., 2011; Schwanz et al., 2020; Wedekind, 2017). Despite potentially widespread occurrence of sex reversal and its diverse implications, this phenomenon is rarely studied, mainly because the identification of genetic sex requires species-specific molecular methods in ectothermic vertebrates (Lambert et al., 2019; Nemesházi et al., 2020). Nevertheless, sex ratios can also be biased by sex-specific tolerances to environmental stress (Afonso et al., 2003; Liwanag et al., 2018; Medina et al., 2002), hence it is important to distinguish between environmental effects on sex-specific mortality versus on sex determination (Geffroy and Wedekind, 2020).

Exposure to high temperatures during the sensitive period of sexual development can result in both female-to-male sex reversal and male-tofemale sex reversal in reptiles, depending on the species (Holleley et al., 2016; Mitchell and Janzen, 2010), whereas in amphibians and fish, heat usually leads to the development of genetically female individuals into phenotypic males via the disruption of the enzymatic machinery of estrogen synthesis (Baroiller and D'Cotta, 2016; Eggert, 2004; Lambert et al., 2018). In taxa prone to heat-induced female-to-male sex reversal, this phenomenon is expected to become more frequent as a result of global climate change, which includes both rises in average temperatures and an increasing frequency of extreme weather events such as heat waves (IPCC, 2014; Spinoni et al., 2015; Tomczyk and Bednorz, 2019). Water temperature in ponds, where the young of many aquatic vertebrates develop, can already reach as high as $30-50{ }^{\circ} \mathrm{C}$ during spring and summer, even under temperate and highland Mediterranean climates (Lambert et al., 2018; Lindauer et al., 2020), and heat waves may have particularly strong effects on populations living in urbanized areas because of the urban heat island effect (Brans et al., 2018; Lambert et al., 2019). Accordingly, trends observed in phenotypic sex ratios suggest that the expected increase in heat-induced male development has already started in some species (Bókony et al., 2017; Grayson et al., 2014).

In addition to climatic challenges, several pollutants that are released into the environment act as endocrine disruptor chemicals (EDCs), which can affect somatic and sexual development by interfering with the hormonal system of animals (Orton and Tyler, 2015). Various EDCs, such as artificial hormones (e.g. contraceptives, growth promoters) and other substances (e.g. pesticides) can cause abnormalities in gonadal development including complete sex reversal (Flament, 2016; Orton and Tyler, 2015) and intersex, a form of incomplete sex reversal where male and female tissues occur simultaneously in the gonads (Abdel-Moneim et al., 2015; Lambert et al., 2019; Ujhegyi and Bókony, 2020). The interactions (i.e. non-additive effects) between these two major environmental factors, i.e. temperature and EDCs, are being investigated with increasing intensity (DeCourten et al., 2019; Noyes and Lema, 2015), as climate change may modify the sensitivity of organisms to EDCs, while the chemicals may damage the capacity of organisms to respond to rapidly changing climatic conditions (Hooper et al., 2013; Noyes and Lema, 2015). Although simultaneous effects of temperature and pollutants on sex have been studied in taxa with temperature-dependent sex determination (DeCourten and Brander, 2017; Mizoguchi and Valenzuela, 2016), very little is known about the combined effects of heat and EDCs on sex reversal, specifically. Results from experiments on fish showed that high temperature amplified the effect of clotrimazole, a female-to-male sex-reversing EDC present in many fungicides (Brown et al., 2015), while treatment with the female sex hormone $17 \beta$-estradiol completely neutralized the female-to-male sex-reversing effect of high temperatures (Kitano et al., 2012, 2007). However, these studies used high concentrations of EDCs, which exceeded environmentally relevant concentrations by an order of magnitude.

In natural waters, hormonally active chemical agents typically occur in low concentrations (Loos et al., 2009), although many of the more persistent EDCs may be enriched in shallow, small water bodies and in their sediments (Bókony et al., 2018). 17 $\alpha$-ethinylestradiol (EE2) is a synthetic female sex hormone used in many contraceptive formulations, hence significant amounts are excreted with urine into wastewater. With the conventional wastewater treatments it cannot be removed completely, so it is often found in surface waters and ground waters worldwide, typically in concentrations of a few ng/L (Bhandari et al., 2015). In vertebrates, EE2 has a strong male-to-female sex-reversing effect (Bhandari et al., 2015; Tamschick et al., 2016), but sensitivity differs among species, with effective concentrations varying from as low as $1.8 \mathrm{ng} / \mathrm{L}$ (Berg et al., 2009; Gyllenhammar et al., 2009) to as high as $500 \mathrm{ng} / \mathrm{L}$ (Tamschick et al., 2016) or even $1 \mu \mathrm{g} / \mathrm{L}$ (Mackenzie et al., 2003). It is unclear if the low concentrations of EE2 that occur in nature can compensate for the female-to-male sex-reversing effect of high temperatures that occur during heat waves, and if there are any other interactions between the effects of heat and EE2 that may influence the ecological consequences of climate change in polluted waters.

In this study, our aim was to investigate the simultaneous effects of high temperature and EE2 on the sexual development of the agile frog (Rana dalmatina), utilizing a molecular marker set recently developed for diagnosing sex reversals in this species (Nemesházi et al., 2020). The agile frog is widespread in Europe, inhabiting natural woodlands as well as urbanized areas, and its population trends are decreasing (Kaya et al., 2009). We performed an experiment to mimic environmentally realistic scenarios in which we exposed tadpoles for a few days to high temperature (simulating a heat wave), EE2 (simulating a short-duration point source pollution), or both. We chose a temperature and EE2 concentration that are relatively high within the range of contemporary environmental conditions, but can be expected to occur with increasing frequency in nature because of climate change (Spinoni et al., 2015; Tomczyk and Bednorz, 2019) and ongoing urbanization. Furthermore, because both high temperature and EE2 are known to influence mortality, growth, and somatic development during early ontogeny in aquatic vertebrates (Gyllenhammar et al., 2009; Hogan et al., 2008; Hu et al., 2019; Lambert et al., 2018; Marques da Cunha et al., 2019; Orizaola and Laurila, 2009; Tompsett et al., 2012), we also investigated whether there is interaction between the effects of high temperature and EE2 on these fitness-related traits besides sexual development.

\section{Materials and methods}

\subsection{Experimental procedures}

On March 8, 2019 we collected 60 agile frog eggs from each of four freshly laid egg masses from three ponds (Apátkút, $47^{\circ} 46^{\prime} 28^{\prime \prime} \mathrm{N}$, $18^{\circ} 59^{\prime} 10.5^{\prime \prime} \mathrm{E}$; Ilona-tó, $47^{\circ} 42^{\prime} 47.7^{\prime \prime} \mathrm{N}, 1^{\circ} 02^{\prime} 25.8^{\prime \prime} \mathrm{E}$; and Katlan, 
$47^{\circ} 42^{\prime} 40^{\prime \prime} \mathrm{N}, 19^{\circ} 02^{\prime} 44.5^{\prime \prime} \mathrm{E}$ ) located in a hilly woodland in Hungary. Eggs were transported to the Experimental Station of the Plant Protection Institute (Centre for Agricultural Research) in Julianna-major, Budapest $\left(47^{\circ} 32^{\prime} 52^{\prime \prime} \mathrm{N}, 18^{\circ} 56^{\prime} 05^{\prime \prime} \mathrm{E}\right)$. Until hatching (17 March), we kept eggs at $16.3 \pm 0.3{ }^{\circ} \mathrm{C}$ (mean $\pm \mathrm{SD}$ ), each of the twelve clutches (families hereafter) separately in 5-L containers $(24 \times 16 \times 13 \mathrm{~cm})$ filled with $1.3 \mathrm{~L}$ reconstituted soft water (RSW, APHA, 1985; Bókony et al., 2020). To ensure sufficient oxygenation, we aerated the water in the containers with aquarium air pumps. When the hatchlings reached the free swimming state (developmental stage 25 according to Gosner, 1960) four days after hatching, we started the experiment by randomly selecting 48 healthy-looking larvae from each of the 12 families and placing them into individual rearing containers. Thus, we had 576 animals, each kept in an individual container $(18 \times 13 \times 12.5 \mathrm{~cm})$ from the start of the experiment until the end of the study. The remaining eggs and tadpoles were released at their ponds of origin.

We combined two temperature treatments $\left(19^{\circ} \mathrm{C}\right.$ or $\left.30^{\circ} \mathrm{C}\right)$ with two hormone treatments ( 0 or $30 \mathrm{ng} / \mathrm{L}$ EE2) and applied their combinations over one of three treatment periods (Fig. S1). We replicated each treatment combination (temperature $\times$ EE $2 \times$ period) four times per family. We chose the nominal concentration of $30 \mathrm{ng} / \mathrm{L} \mathrm{EE} 2$ for two reasons. First, this value is environmentally realistic; for example, the average EE2 concentration in ponds, lakes and rivers is a few ng/L (Avar et al., 2016; Mina et al., 2018; Rechsteiner et al., 2020), but higher concentrations up to $98.33 \mathrm{ng} / \mathrm{L}$ occur at point sources of pollution (Jakab et al., 2020). Also, in a previous study (Bókony et al., 2018) we found EE2 in the sediment of a pond where agile frogs breed. Second, a similar concentration $(0.09 \mathrm{nM}$, equivalent to $27 \mathrm{ng} / \mathrm{L})$ was shown to cause female-biased sex ratios in the common frog (Rana temporaria), a close relative of agile frogs (Pettersson and Berg, 2007). We chose a $30{ }^{\circ} \mathrm{C}$ temperature treatment because it represents an environmentally relevant extreme that occurs in the ponds where we collected eggs for this experiment (Szederkényi et al., unpublished data) and in other water bodies where amphibians breed and develop in climates similar to ours (Lambert et al., 2018; Lindauer et al., 2020).

Outside the treatment period, we reared tadpoles at $20.1 \pm 1.1^{\circ} \mathrm{C}$ (mean $\pm \mathrm{SD}$ ), their individual containers were filled with $1 \mathrm{~L} \mathrm{RSW}$, arranged in a randomized block design where each block contained all members of one family. We changed the rearing water two times a week (the RSW was aerated for at least $12 \mathrm{~h}$ before each water change), and we fed tadpoles ad libitum with slightly boiled chopped spinach. The light:dark cycle was adjusted weekly to outdoor conditions, starting with $12: 12 \mathrm{~h}$ in late March which we gradually changed to $14: 10 \mathrm{~h}$ by the end of April. Each tadpole was exposed to a treatment period of six days, starting either 2,8 , or 14 days after start of the experiment (period 1: developmental stages 25-28, period 2: developmental stages 29-32, period 3: developmental stages 33-37). During the treatment period, treated tadpoles experienced the following changes in rearing conditions. The volume of rearing water was increased to $1.7 \mathrm{~L}$, and the container was placed in an $80 \times 60 \times 12 \mathrm{~cm}$ tray filled with ca. $18 \mathrm{~L}$ tap water (for further details see Supplementary Methods). The tap water was circulated using a Tetra WP 300 aquarium water pump and heated using a Tetra HT 300 aquarium heater (Fig. S2). This arrangement ensured homogeneous water temperatures in the tray and among the tadpole rearing containers. Each tray hosted twelve containers, one from each family, resulting in four trays in each treatment group. During the treatment period we changed the water of treated animals every other day with temperature-adjusted and chemical-administered RSW (according to experimental treatments) and fed tadpoles with a reduced amount of spinach (for details see Supplementary Methods) to prevent water fouling in the heat treatments. During treatment, the water of all treated tadpoles contained a minute amount of ethanol (1 $\mu \mathrm{L} 96 \%$ ethanol in $100 \mathrm{~L} \mathrm{RSW}$ ) because this solvent was necessary for EE2 treatment. This ethanol concentration is much lower than those that were shown to damage tadpoles (Fainsod and Kot-Leibovich, 2018; Peng et al., 2005; Taylor and Brundage, 2013) and in a previous experiment we showed that the same ethanol concentration did not result in skewed sex ratio or in any gonadal abnormalities in agile frogs (Bókony et al., 2020).

At the beginning of each treatment period we filled the trays with $19{ }^{\circ} \mathrm{C}$ water and placed the tadpoles' containers (with freshly changed RSW) in the trays. In case of treatments involving elevated temperature, we subsequently turned on the heating. Thereby, water temperature gradually increased to $30^{\circ} \mathrm{C}$ over the course of $2 \mathrm{~h}$ and was maintained at $29.9 \pm 0.2{ }^{\circ} \mathrm{C}$ (mean $\pm \mathrm{SD}$ ) in tadpoles' containers. After six days of treatment, we turned off the heating in the trays, replaced the water in the rearing containers with $1 \mathrm{~L}$ fresh, $30{ }^{\circ} \mathrm{C}$ RSW, and transferred them back to their original place in the laboratory. These procedures ensured that the tadpoles were not exposed to a sudden change in temperature. In the $19{ }^{\circ} \mathrm{C}$ treatments, we applied the same protocol, except that the water in the trays was not heated, only circulated; water temperature in these treatments was $18.8 \pm 0.3^{\circ} \mathrm{C}$ (mean \pm SD) in the tadpoles' containers (for more details see Supplementary Methods).

To expose tadpoles to EE2 we used an analytical standard obtained from Sigma (E4876). The stock solution was prepared by dissolving 30 mg EE2 in $10 \mathrm{~mL} \mathrm{96 \%} \mathrm{ethanol.} \mathrm{At} \mathrm{the} \mathrm{beginning} \mathrm{and} \mathrm{at} \mathrm{each} \mathrm{water}$ change during the treatment period, we added $1 \mu \mathrm{L}$ of the stock solution into $100 \mathrm{~L} \mathrm{RSW}$, resulting in $30 \mathrm{ng} / \mathrm{L} \mathrm{EE} 2$ in the water of hormonetreated tadpoles (and yielding the same ethanol concentration as in the water of tadpoles not treated with EE2). To determine how EE2 concentration changed during treatment, we took samples from the rearing water of treated tadpoles three times during the experiment. On each occasion, we collected one sample from each EE2 treatment (yielding a total of three samples from $19{ }^{\circ} \mathrm{C}$, and another three from $30{ }^{\circ} \mathrm{C}$, over the experiment) right before water change (i.e. two days after the nominal concentration was applied). Each sample $(1 \mathrm{~L})$ was collected into an amber PET flask, and transported to the analytical laboratory of the Centre for Agricultural Research in Martonvásár, where they were frozen and stored at $-80{ }^{\circ} \mathrm{C}$. Subsequent UPLC-UniSpray ${ }^{\mathrm{TM}}$ MS/MS analysis (for detailed methods see Bókony et al., 2021) showed that, over two days of treatment, the initial concentration has approximately halved at $19^{\circ} \mathrm{C}$ (measured concentrations: $14.27,15.93$, $16.6 \mathrm{ng} / \mathrm{L})$, and dropped to about a quarter at $30^{\circ} \mathrm{C}(6.42,7.53,7.99$ $\mathrm{ng} / \mathrm{L})$. We did not take samples from the water of tadpoles that were not treated with EE2, because our previous experiment showed that there is no EE2 contamination in the RSW we use in our laboratory (Ujhegyi and Bókony, 2020).

By starting the treatments 6,12 , or 18 days after hatching, we aimed to cover the majority of the larval period without risking that tadpoles would start to metamorphose during treatment, because a preliminary experiment showed that exposure to $30{ }^{\circ} \mathrm{C}$ during late tadpole development may result in increased mortality in agile frogs (unpublished data). We had no prior information on whether and when agile frogs have a sensitive time window for sex determination, but studies on other closely related species indicated such a time window either during early (Hogan et al., 2008) or mid-late larval development (Lambert et al., 2018). When tadpoles approached metamorphosis, we checked the rearing containers daily. When an individual reached developmental stage 42 (emergence of forelimbs), we noted the time until metamorphosis and measured body mass using a laboratory scale $( \pm 0.1 \mathrm{mg})$. We changed the water volume to $0.1 \mathrm{~L}$ in the respective rearing container, slightly tilted it to prevent drowning, and covered it with a perforated, transparent lid to prevent escape. When metamorphosis was complete (developmental stage 46, disappearance of the tail), we moved the animal into a new rearing container, lined with wet paper towels as a substrate and a piece of egg carton as a shelter, which we changed every other week. Froglets were fed ad libitum with springtails and small (2-3 $\mathrm{mm}$ ) crickets sprinkled with a 3:1 mixture of Reptiland 76280 (Trixie Heimtierbedarf GmbH \& Co. KG, Tarp, Germany) and Promotor 43 (Laboratorios Calier S.A., Barcelona, Spain) containing vitamins, minerals and amino-acids.

We dissected the animals 6-8 weeks after metamorphosis (14-16 
weeks after they reached the free-swimming tadpole stage). At this age the gonads are well differentiated in this species (Bernabò et al., 2011; Ogielska and Kotusz, 2004). When a froglet reached this age, we measured its body mass to the nearest $0.01 \mathrm{~g}$ and euthanized it using a water bath containing $6.6 \mathrm{~g} / \mathrm{L}$ MS-222 buffered to neutral $\mathrm{pH}$ with the same amount of $\mathrm{Na}_{2} \mathrm{HPO}_{4}$. After dissection, we cut out the entire digestive tract and measured its mass to the nearest $0.01 \mathrm{~g}$, because many animals' guts contained food although we had not fed them for $2-4$ days before dissection. We examined the gonads and the associated fat bodies under an Olympus SZX12 stereomicroscope at $16 \times$ magnification (Fig. S3). We recorded whether the animal had fat bodies and categorized phenotypic sex as male (testes), female (ovaries), or uncertain (abnormally looking gonads). We carefully removed the gonads and fixed them in neutral-buffered $10 \%$ formalin (Sigma 1.00496) for histological analysis. We took a tissue sample (hind feet) from each froglet and stored it in $96 \%$ ethanol until DNA extraction.

\subsection{Histology}

In a preliminary study we observed that sex categorized based on gonadal anatomy matched sex categorized by histology in all of 32 agile frogs (17 males, 15 females) that had been raised without any chemical treatment at $19{ }^{\circ} \mathrm{C}$ (Nemesházi et al., 2020). Furthermore, in a previous study we found that spontaneous female-to-male sex reversal in agile frogs resulted in normal testicular histology, except for two female-to-male sex-reversed individuals that had normal testis anatomy and histology with a single oogonium detected in each (Nemesházi et al., 2020), which is similar to findings in another frog species (Lambert et al., 2019). Therefore, to minimize the costs of histological analysis in the present study, we chose to analyze gonad histology only in those froglets for which phenotypic sex was ambiguous based on gonad anatomy (Fig. S3). In these cases, when phenotypic sex could be clearly identified by histology, the animal was considered as female or male; if mixed-sex tissues were found, the individual was considered as intersex.

Histological sections were prepared as described in the Supplementary Methods. For each individual, we examined 5-6 sections; ovaries were identified by the presence of diplotene oocytes, and testes by seminiferous tubules and spermatogonia (Fig. S4).

\subsection{Genetic sexing}

DNA was extracted using Geneaid Genomic DNA Extraction Kit for animal tissue (Thermo Fisher Scientific) following the manufacturer's protocol, except that digestion time was $2 \mathrm{~h}$. Genetic sexing was performed using a recently developed molecular marker set which has been validated for agile frog populations in our study area (Nemesházi et al., 2020). In short, we first tested all froglets for marker Rds3 ( $\geq 95 \%$ sex linkage) applying high-resolution melting (HRM) and accepted an individual to be concordant male or female if its Rds3 genotype was in accordance with its phenotypic sex. Individuals that appeared to be sex-reversed based on Rds3 were tested for marker Rds1 ( $\geq 89 \%$ sex linkage) using PCR, and were accepted to be sex-reversed only if both markers confirmed sex reversal. Individuals with discrepant genotyping results (i.e. contradiction between Rds1 and Rds3) were considered to be of unknown genetic sex. All details of HRM and PCR methods, and more information about the sex markers are described in Nemesházi et al. (2020). As the agile frog has an XX/XY sex-chromosome system (Nemesházi et al., 2020), genotypes XY and XX mean genetic males and genetic females, respectively.

\subsection{Statistical analyses}

We analyzed the effects of treatments using pre-planned comparisons (Ruxton and Beauchamp, 2008). For each dependent variable, we ran a model (see model specifications below) containing the three-way interaction of temperature treatment, EE2 treatment, and treatment period; block (family) was entered as random factor in each model. Then, using the model estimates we tested the overall effect of temperature, EE2, and their interaction within each treatment period by calculating a priori linear contrasts (Lenth et al., 2020; Ruxton and Beauchamp, 2008). We evaluated the significance of linear contrasts both with and without correction for multiple testing; correction was applied by using the false discovery rate (FDR) method (Pike, 2011). All analyses were conducted in ' $\mathrm{R}$ ' (version 3.6.3; R Core Team, 2020), with the 'emmeans' function of 'emmeans' package for linear contrasts. Sample sizes are given in Table S1.

For the analysis of survival, we used Cox's proportional hazards model ('coxme' function of the 'coxme' package). Survival was categorized as 1: died during treatment, 2 : died after treatment, but before the start of metamorphosis, 3: died during metamorphosis, 4: died after metamorphosis, before dissection, 5: the froglet survived until dissection. Animals that died before their respective treatment period (16 individuals, see Table S1) were left out of the analysis of survival. We entered survival as the dependent variable, and treated category 5 as censored observations (i.e. individuals that did not die before dissection were neither excluded nor treated as dead; instead, they were included in the analysis with the information that they were last observed alive after the individuals in category 4 died).

To analyze time to metamorphosis, body mass at metamorphosis, and body mass at dissection, we used linear mixed-effects models ('lme' function of the 'nlme' package). In the analysis of time to metamorphosis, we also allowed the variances to differ among treatment groups using the 'varIdent' function, because graphical model diagnostics indicated heterogeneous variances. When analyzing body mass at dissection, we subtracted gut mass from total body mass to provide a measure for lean body mass (i.e. without food remains), and we included the individual's age (number of days from finishing metamorphosis until dissection) as a covariate and the combination of genetic and phenotypic sex (i.e. a 3-category factor: concordant male, concordant female, or sex-reversed individual) as a fixed factor. From the latter analysis, we excluded seven individuals for which genetic sex was unknown and three individuals that had intersex gonads.

For the analyses of the presence/absence of fat bodies and phenotypic sex ratio, we used generalized linear mixed-effects models with binomial error distribution and a logit-link function ('glmmPQL' function of the 'MASS' package). The seven individuals with unknown genetic sex and the three with intersex gonads were excluded from both models. In the model of fat bodies, the combination of genetic and phenotypic sex (concordant male, concordant female, or sex-reversed individual) was added as fixed factor, and age of the froglets was included as a covariate.

For the analysis of sex reversal, we could not apply the same modeling framework as for sex ratio, because of separation (i.e. the number of sex-reversed individuals was zero in certain treatment groups). Therefore, we used Firth's bias-reduced logistic regression ('logistf' function of the 'logistf' package), which yields less biased estimates when separation is present in the data as compared to logistic regression. Because this method does not accommodate random effects and linear contrasts, we could not include block as a random factor, and we obtained our pre-planned comparisons as the model estimates from three separate analyses, one for each of the three treatment periods. We restricted this analysis to genetically female individuals, and the dependent variable was phenotypic sex, i.e. whether or not the individual was sex-reversed.

\section{Results}

\section{1. $\operatorname{Sex}$}

Regardless of treatment timing, phenotypic sex ratio and sex-reversal rate were both significantly affected by heat treatment, whereas EE2 and its interaction with heat had no significant effects (Tables S1-4). Heat 
treatment significantly increased the proportion of phenotypic males by inducing sex reversal in genetically female individuals (Tables S1-4, Fig. 1): overall, 58 out of 199 genetically female individuals became phenotypic males, 55 of which received heat treatment. This female-tomale sex-reversing effect was strongest if heat was applied in the third period and weakest if it was applied in the second period (Tables S1, S3, S4). Additionally, the genetic sex ratio of froglets surviving to dissection was also male-biased for animals that received heat treatment in the first period (11 XX to $27 \mathrm{XY}$ individuals, binomial test: $P=0.014$ ); all other treatment groups had genetic sex ratios close to 1:1 (Table S1). Furthermore, we found three intersex individuals which came from different treatment groups: one received heat but no EE2 in the second period, one received EE2 but no heat in the third period, and one received both EE2 and heat in the third period. These animals were genetic females with abnormally looking gonads (Fig. S3) that were identified as ovotestes in the histological analysis (Fig. S4). We could not identify the genetic sex of seven phenotypically male individuals that received heat treatment, because in all these cases, the Rds3 genotype (corresponding to the locus with the highest sex linkage in our marker set) indicated sex reversal from female to male, whereas the Rds1 genotype suggested the genetic sex to be male.

\subsection{Survival, metamorphosis, and growth}

In each of the three treatment periods, all dependent variables were significantly affected by heat (Tables S1-3), whereas EE2 and its interaction with heat had no significant effects (Tables S1-3) except for juvenile body mass (Table S2). Heat treatment significantly decreased survival (Tables S2-3), delayed metamorphosis (Tables S2-3, Fig. 2), decreased body mass at metamorphosis (Tables S2-3, Fig. 2), and increased the proportion of animals that had no fat bodies (Tables S1-3). Most of these effects were similar across the three treatment periods, except for the time to metamorphosis, which was delayed significantly more if heat was applied to younger tadpoles (Tables S2-3). For body mass of froglets at dissection, besides the main effect of heat, the threeway interaction (heat $\times$ EE2 $\times$ period) was also significant (Table S2). Heat applied in the first period increased froglet mass regardless of EE2 treatment, but for the other two periods the heat $\times \mathrm{EE} 2$ interaction was significant (Table S3, Fig. 2). Without heat, EE2 applied in the second period tended to increase body mass, whereas EE2 applied in the third period decreased mass, but these effects were reversed in the heattreated groups (Fig. 2). Thus, only the chemically untreated (no EE2) animals in the second period and the EE2-treated animals in the third period showed significant increase in body mass in response to heat (Fig. 2). Additionally, the combination of genetic and phenotypic sex also affected froglet mass significantly (Table S2): sex reversal reduced body mass by $5 \%$ on average, to $1.15 \pm 0.03 \mathrm{~g}$ compared to $1.22 \pm 0.02 \mathrm{~g}$ in concordant females and $1.19 \pm 0.02 \mathrm{~g}$ in concordant males (Table S5) across all treatment groups (Fig. S5).

\section{Discussion}

In this study, we investigated the simultaneous effects of ecologically relevant larval exposure to high temperature and EE2 on the sexual development, survival, growth and somatic development of the agile frog. We found that all measured variables were significantly affected by the heat treatment regardless of its timing, whereas EE2 and its interaction with heat had no significant effects except on froglet body mass. The simulated heat wave caused female-to-male sex reversal and had long-term negative effects on several fitness-related traits, suggesting that populations of the agile frog (and other species with similar sensitivity to heat) face multiple threats from climate change due to skewed sex ratios and poor survival, which are not countered by environmental concentrations of male-to-female sex-reversing pollutants like EE2.

In our experiment, the lack of EE2 effects on sex was unexpected, given that a similar concentration $(27 \mathrm{ng} / \mathrm{L})$ caused female-biased sex ratios in the closely related common frog (Pettersson and Berg, 2007). This discrepancy confirms that EE2 sensitivity can vary not only among phylogenetically distant lineages (Tamschick et al., 2016) but also within a genus (Mackenzie et al., 2003). A notable difference is that previous studies showing female-biased sex ratios in response to EE2 in amphibians either exposed individuals throughout their entire larval development and/or used doses much higher than the environmentally realistic concentrations (Berg et al., 2009; Gyllenhammar et al., 2009; Hogan et al., 2008; Mackenzie et al., 2003; Pettersson and Berg, 2007; Tompsett et al., 2013, 2012). Our treatments were ecologically relevant in terms of both magnitude and duration, as EE2 typically occurs in surface waters in the $\mathrm{ng} / \mathrm{L}$ concentration range and its presence is usually not constant, possibly due to photolysis and adsorption to suspended solids and sediment (Avar et al., 2016; Bhandari et al., 2015; Jakab et al., 2020; National Center for Biotechnology Information, 2020). Therefore, our findings suggest that population persistence in the agile frog (and other species with similar sensitivities) is threatened more by climate change than by xenoestrogens.

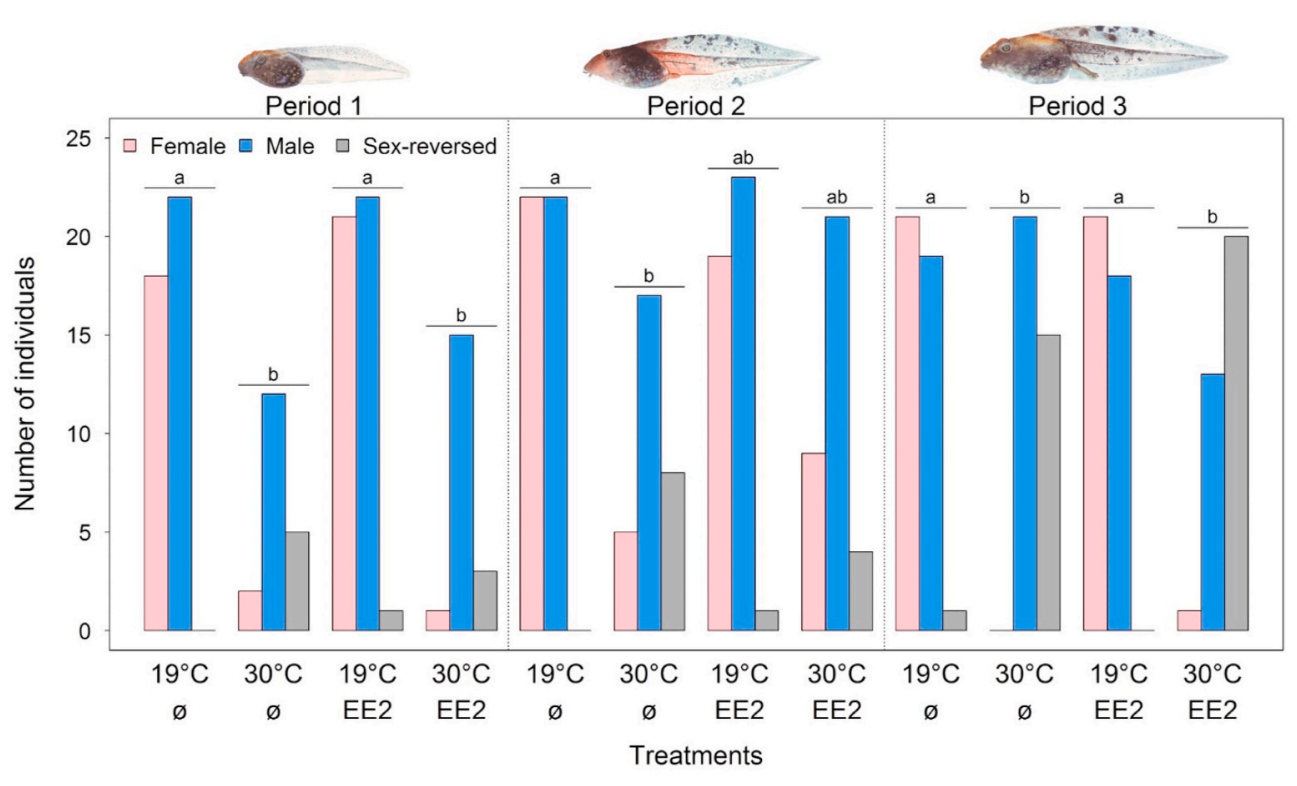

Fig. 1. Effects of heat $\left(30{ }^{\circ} \mathrm{C}\right.$ versus $\left.19{ }^{\circ} \mathrm{C}\right)$ and EE2 (30 ng/L, marked as EE2, versus none, marked with a $\varnothing$ symbol) treatments on phenotypic sex ratio and female-to-male sex-reversal in juvenile agile frogs treated in one of three different periods of larval development. Letters above the bars indicate the significant differences between treatment groups (in each panel, groups marked with different letters differ significantly whereas groups marked with the same letter do not differ according to FDR-corrected Pvalues from pairwise comparisons). 


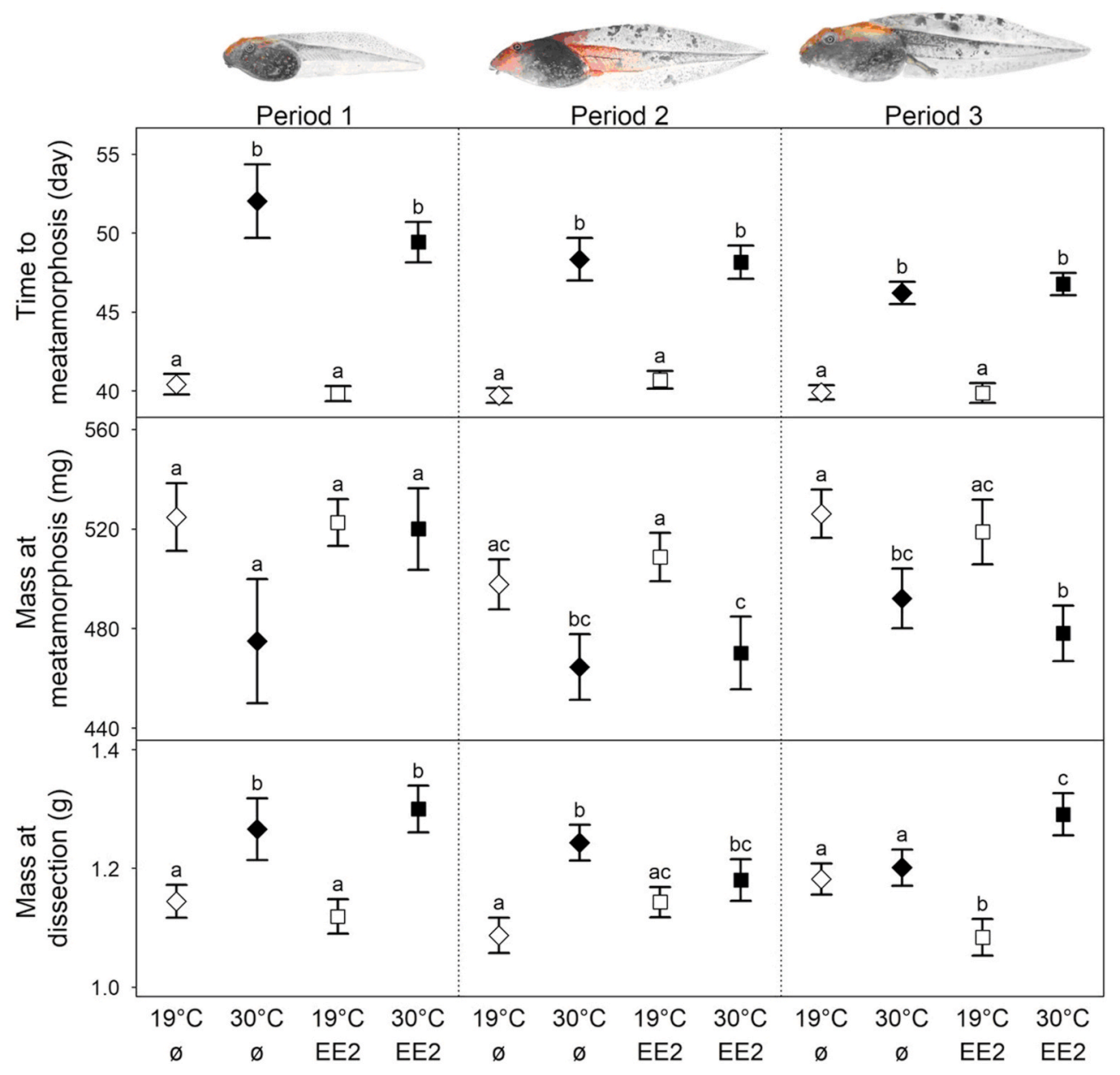

Fig. 2. Effects of heat $\left(30^{\circ} \mathrm{C}\right.$ versus $\left.19^{\circ} \mathrm{C}\right)$ and EE2 (30 ng/L, marked as EE2, versus none, marked with a $\varnothing$ symbol) treatments on larval developmental time, body mass at metamorphosis, and the body mass of juvenile frogs at dissection. Error bars show the means and standard errors estimated from the models in Table S2. Letters above error bars indicate the significant differences between treatment groups (in each panel, groups marked with different letters differ significantly whereas groups marked with the same letter do not differ according to FDR-corrected $P$-values from pairwise comparisons).
Our experimental simulation of a six-days heat wave confirmed that high temperatures during early ontogeny can result in male-biased sex ratios, which was found for several other amphibian and fish species in previous studies. However, these earlier experiments usually applied heat treatment throughout the entire larval period (Chardard et al., 2004; Dournon et al., 1990; Eggert, 2004; Flament, 2016; Lambert et al., 2018; Ospina-Alvarez and Piferrer, 2008), which may not represent ecologically realistic temperature regimes in natural water bodies under current climatic conditions (Lambert et al., 2018; Lindauer et al., 2020). The bias towards phenotypic males in our experiment was mostly due to sex reversal, as $30-100 \%$ of genetically female individuals (depending on treatment) developed testes after experiencing the heat weave. Thus, our study shows that even a relatively short hot spell, lasting only six days, can lead to a preponderance of males via sex reversal. Theoretical models suggest that such sex-ratio skews, due to increasing frequency of climate-driven female-to-male sex reversal, may have detrimental consequences for population viability (Bókony et al., 2017; Nemesházi et al., 2021; Quinn et al., 2011; Schwanz et al., 2020; Wedekind, 2017). Additionally, it seems that the high temperature in our experiment caused sex-dependent mortality in the youngest tadpoles, because genetic sex ratio at dissection was also male-biased when heat was applied in the first period. This highlights the importance of molecular sexing methods for diagnosing sex reversals and disentangling the mechanisms by which anthropogenic disturbances cause skewed sex ratios, i.e. sex reversal vs. sex-biased mortality (Geffroy and Wedekind, 2020; Lambert et al., 2016).

In many ectothermic vertebrates, there is a thermosensitive period (TSP), a time window of limited length during early development, during which environmental temperatures can influence whether the bipotent gonad commits to male or female development (Eggert, 2004; Flament, 2016; Mitchell and Janzen, 2010; Ospina-Alvarez and Piferrer, 2008). During the TSP the gonads are histologically undifferentiated, and the end of the TSP corresponds to the beginning of the meiotic prophase of ovarian differentiation (reviewed in Baroiller and Guiguen, 2001; Chardard et al., 2004). In the agile frog ovarian differentiation was reported to start at developmental (Gosner) stage 31 (Falconi et al., 2001), although gonad development in anurans may be tied to chronological age rather than to the stage of somatic development (Ogielska and Kotusz, 2004). In our experiment, tadpoles were between 6 and 24 days after hatching (developmental stages 25-37) during the treatment periods, and heat-induced sex-reversal occurred in all three 6-days periods. Thus, while our experiment does not allow for identifying the exact start and end of the TSP in agile frogs, it seems that it spans at least one quarter of their larval development. We propose that TSP length and timing deserve more attention in ectothermic vertebrates that are susceptible to sex reversal, because longer and later-occurring TSP may increase the risk that it coincides with extreme temperatures (e.g. early-summer heat waves) and thereby causes sex reversal or gonadal abnormalities.

Notably, three individuals in our experiment out of 253 that did not receive heat treatment showed a mismatch between genetic and phenotypic sex. This may be explained by misdiagnosed genetic sex due to sex-chromosome recombination or mutation, which occur in amphibians and make genetic sexing difficult (Alho et al., 2010; Lambert et al., 2016; Stöck et al., 2013). Alternatively, sex reversal may have occurred naturally, which has been reported to take place occasionally in several species (Holleley et al., 2016; Lambert, 2015; Lambert et al., 2019; Nemesházi et al., 2020) due to random processes affecting sex 
determination (Perrin, 2016). With this latter interpretation, here we found a $1.2 \%$ baseline rate of female-to-male sex reversal in agile frogs, which is similar to the $4.8 \%$ found in a previous study on lab-raised agile frogs (Nemesházi et al., 2020). In the wild, however, the frequency of female-to-male sex-reversed individuals was considerably higher, especially in anthropogenic habitats including urban ponds (Nemesházi et al., 2020). These findings combined with our current experimental results suggest that anthropogenic stressors, such as heat waves exacerbated by the urban heat island effect, increase sex-reversal rates above their baseline in natural populations.

Our current study also provides indirect but much-needed information about the relationship between sex reversal and individual fitness prospects. The results of our experiment show that, when sex reversal is triggered by heat stress, it is accompanied by reduced survival, slower development, lower body mass at metamorphosis, and less fat before the first winter hibernation. These changes suggest that sex reversal is associated with inferior fitness in agile frogs, corroborating a previous study (Nemesházi et al., 2020) in which a much smaller sample of spontaneously female-to-male sex-reversed froglets showed several signs of poor condition and increased physiological stress. These findings are in line with the emerging view that sex reversal is mechanistically linked with physiological stress, as studies on fish and reptiles suggest that extreme temperature may be one out of many stressors that influence sex development via the activation of the hypothalamus-pituitary-interrenal axis (Castañeda Cortés et al., 2019; Fernandino et al., 2013) or cellular pathways of the calcium and redox regulation system (Castelli et al., 2020). However, empirical data on the relative fitness of sex-reversed individuals in nature are so far few and controversial (Holleley et al., 2016; Senior et al., 2012); for example, despite the poor health of female-to-male sex-reversed agile frogs in the laboratory, body mass of female-to-male sex-reversed adults did not differ from concordant males' in free-living populations (Nemesházi et al., 2020).

In our current experiment, the negative effect of heat treatment on metamorphic size disappeared after ca. two months: body mass at dissection was larger in heat-treated animals than in their control siblings. This result might be explained with compensatory growth (Hector et al., 2012; Squires et al., 2010). Alternatively, the environmental matching hypothesis claims that individuals that developed under poor conditions can have higher fitness later in life than those that developed under good conditions, if adult environmental conditions are also poor (Monaghan, 2008). Whatever mechanism allowed for faster growth after metamorphosis, it pertained only to those heat-treated individuals that developed concordant sex; those that underwent female-to-male sex reversal had reduced body mass as juveniles. This suggests that heat-induced sex reversal constrains juvenile growth, or alternatively, individuals with the least inherent potential for juvenile growth performance are the most likely to respond to heat with sex reversal. This latter possibility might even be an adaptive strategy if reduced growth is more detrimental for fitness in females than in males (Baroiller and D'Cotta, 2016; Schwanz et al., 2016), which seems likely in agile frogs and many other ectothermic vertebrates where mature females are larger than mature males.

Juvenile body mass was the only trait in our study that was affected by EE2, but only in some treatment combinations. Although differences in EE2 effects between heat treatment might have been due to the difference in EE2 dissipation rate (which resulted in lower concentrations after 2 days at $30^{\circ} \mathrm{C}$ than at $19{ }^{\circ} \mathrm{C}$ ), we found no consistent pattern to support this: the EE2 effects were not consistently higher or lower in the heated group than in the control group. When treatment was applied in the second period, EE2 counteracted the heat-induced increase in body mass, whereas in the third period, EE2 decreased mass without heat but contributed to mass increase when combined with heat. These results indicate that heat waves and EE2 pollution in water bodies may have non-additive effects on fitness via influencing body mass even when EE2 does not cause male-to-female sex reversal in environmentally relevant concentrations. The mechanisms behind these interactions are unclear, but both high temperature and estrogens may influence the hormonal regulation of growth, including thyroid hormones, prolactin and growth hormone (Hogan et al., 2008; Hu et al., 2019). For example, a study on salamander larvae found that high temperature decreased the gene expression of growth hormone and its brain receptors during treatment but increased it after treatment (Hu et al., 2019). In amphibians, growth is governed by different hormones in different stages of development, which might explain the stage-dependent effects of EE2 (Hogan et al., 2008).

\section{Conclusions}

Taken together, our experiment showed that a six-days heat wave induces female-to-male sex reversal and reduces growth, development and survival, whereas exposure to environmentally relevant concentration of EE2 is unlikely to temper the female-to-male sex-reversing effects of high temperature. Nevertheless, EE2 and heat had nonadditive effects on juvenile body mass, and additionally, sex reversal was associated with reduced mass regardless of treatment. These results highlight that climate change and chemical pollution may have intricate consequences for individual fitness and population persistence in species with environmentally sensitive sex determination. Understanding these effects is essential for the conservation of biodiversity in our humanmodified world.

\section{Funding}

The study was funded by the National Research, Development and Innovation Office of Hungary (NKFIH, grants 115402 and 135016 to V. B., 124375 to A.H., and 124708 to O.I.H.). The authors were supported by the János Bolyai Research Scholarship of the Hungarian Academy of Sciences (to V.B., A.H., and O.I.H.), the ÚNKP-20-5 New National Excellence Program of the Ministry for Innovation and Technology from the source of the National Research, Development and Innovation Fund ("Bolyai + Scholarship" to V.B. and A.H.), the Ministry of Human Capacities (National Program for Talent of Hungary, NTP-NFTÖ-18-B0412 to V.V., NTP-NFTÖ-17-B-0317 to E.N.), and the Austrian Agency for International Cooperation in Education \& Research (OeAD-GmbH; ICM-2019-13228 to E.N.). None of the funding sources had any influence on the study design, collection, analysis, and interpretation of data, writing of the paper, or decision to submit it for publication.

All experimental procedures were approved by the Ethical Commission of the Plant Protection Institute and carried out according to the permits issued by the Government Agency of Pest County (Department of Environmental Protection and Nature Conservation, PE/KTF/3596-6/ 2016, PE/KTF/3596-7/2016 and PE/KTF/3596-8/2016), the Budapest Metropolitan Municipality (Department of City Administration, FPH061/2472-4/2017) and the EC Directive 86/609/EEC for animal experiments (http://europa.eu.int/scadplus/leg/en/s23000.htm).

\section{Author statement}

Zsanett Mikó;: Methodology, Investigation, Data curation, Formal analysis, Writing - original draft, Writing - review \& editing, Visualization. Edina Nemesházi: Methodology, Investigation, Writing - review \& editing. Nikolett Ujhegyi: Methodology, Investigation, Writing - review \& editing. Viktória Verebélyi: Investigation, Writing - review \& editing. János Ujszegi: Methodology, Investigation, Writing - review \& editing. Andrea Kásler: Investigation, Writing - review \& editing. Réka Bertalan: Investigation, Data curation, Writing - review \& editing. Nóra Vili: Investigation, Writing - review \& editing. Zoltán Gál: Investigation, Writing - review \& editing. Orsolya I. Hoffmann: Investigation, Writing - review \& editing. Attila Hettyey: Methodology, Investigation, Writing - review \& editing, Funding acquisition. Veronika Bókony: Conceptualization, Methodology, Investigation, Data curation, Formal analysis, 
Writing - original draft, Writing - review \& editing, Visualization, Supervision, Funding acquisition.

\section{Declaration of competing interest}

The authors declare that they have no known competing financial interests or personal relationships that could have appeared to influence the work reported in this paper.

\section{Acknowledgements}

We are grateful to Kamirán Á. Hamow and Mihály Dernovics for the chemical analysis of water samples. We thank Árpád Ferincz, Ádám Staszny, Lilianna Olimpia Pap, Vera Juhász and András Weiperth for sharing their unpublished data on EE2 concentrations in Hungarian streams. We are grateful to all members of the Lendület Evolutionary Ecology Research Group for insightful discussions, and Márk Szederkényi, Eszter Nádai-Szabó, Csenge Kalina, Zsófia Boros, Boglárka Jaloveczki, Stephanie Orf and Gergely Tarján for help with animal care and data archiving. We thank Gergö Tholt and the NÖVI Department of Zoology for allowing us to use their stereomicroscope and camera and for providing helpful advice. We are grateful to Renáta Pop and the Department of Pathology, University of Veterinary Medicine Budapest for preparing histological sections, and to Beata Rozenblut-Kościsty and Maria Ogielska for help with interpreting histological images. We thank Bálint Bombay for the paintings of agile frog tadpoles.

\section{Appendix A. Supplementary data}

Supplementary data to this article can be found online at https://doi. org/10.1016/j.envpol.2021.117464.

\section{References}

Abdel-Moneim, A., Coulter, D.P., Mahapatra, C.T., Sepúlveda, M.S., 2015. Intersex in fishes and amphibians: population implications, prevalence, mechanisms and molecular biomarkers. J. Appl. Toxicol. 35, 1228-1240. https://doi.org/10.1002/ jat.3204.

Afonso, L.O.B., Basu, N., Nakano, K., Devlin, R.H., Iwama, G.K., 2003. Sex-related differences in the organismal and cellular stress response in juvenile salmon exposed to treated bleached kraft mill effluent. Fish Physiol. Biochem. 29, 173-179. https:// doi.org/10.1023/B:FISH.0000035939.81588.09.

Alho, J.S., Matsuba, C., Merilä, J., 2010. Sex reversal and primary sex ratios in the common frog (Rana temporaria). Mol. Ecol. 19, 1763-1773. https://doi.org/ 10.1111/j.1365-294X.2010.04607.x.

APHA, 1985. Standard Methods for the Examination of Wastewater, sixteenth ed. American Public Health Association, Washington DC.

Avar, P., Zrínyi, Z., Maász, G., Takátsy, A., Lovas, S., G-Tóth, L., Pirger, Z., 2016. $\beta$-Estradiol and ethinyl-estradiol contamination in the rivers of the Carpathian Basin. Environ. Sci. Pollut. Res. Int. 23, 11630-11638. https://doi.org/10.1007/s11356016-6276-2.

Baroiller, J.-F., D'Cotta, H., 2016. The reversible sex of gonochoristic fish: insights and consequences. Sex. Dev. 10, 242-266. https://doi.org/10.1159/000452362.

Baroiller, J.-F., Guiguen, Y., 2001. Endocrine and environmental aspects of sex differentiation in gonochoristic fish. In: Scherer, G., Schmid, M. (Eds.), Genes and Mechanisms in Vertebrate Sex Determination. Birkhäuser, Basel, pp. 177-201. https://doi.org/10.1007/978-3-0348-7781-7_9.

Berg, C., Gyllenhammar, I., Kvarnryd, M., 2009. Xenopus tropicalis as a test system for developmental and reproductive toxicity. J. Toxicol. Environ. Health. A 72, 219-225. https://doi.org/10.1080/15287390802539079.

Bernabò, I., Sperone, E., Tripepi, S., Brunelli, E., 2011. Toxicity of chlorpyrifos to larval Rana dalmatina: acute and chronic effects on survival, development, growth and gill apparatus. Arch. Environ. Contam. Toxicol. 61, 704-718. https://doi.org/10.1007/ s00244-011-9655-1.

Bernanke, J., Köhler, H.-R., 2009. The impact of environmental chemicals on wildlife vertebrates. In: Whitacre, D.M. (Ed.), Reviews of Environmental Contamination and Toxicology. Springer New York, New York, NY, pp. 1-47.

Bhandari, R.K., Deem, S.L., Holliday, D.K., Jandegian, C.M., Kassotis, C.D., Nagel, S.C., Tillitt, D.E., Vom Saal, F.S., Rosenfeld, C.S., 2015. Effects of the environmental estrogenic contaminants bisphenol A and $17 \alpha$-ethinyl estradiol on sexual development and adult behaviors in aquatic wildlife species. Gen. Comp. Endocrinol. 214, 195-219. https://doi.org/10.1016/j.ygcen.2014.09.014.

Bókony, V., Kövér, S., Nemesházi, E., Liker, A., Székely, T., 2017. Climate-driven shifts in adult sex ratios via sex reversals: the type of sex determination matters. Philos. Trans. R. Soc. Lond. B Biol. Sci. 372, 20160325. https://doi.org/10.1098/ rstb.2016.0325.
Bókony, V., Ujhegyi, N., Hamow, K.Á., Bosch, J., Thumsová, B., Vörös, J., Aspbury, A.S., Gabor, C.R., 2021. Stressed tadpoles mount more efficient glucocorticoid negative feedback in anthropogenic habitats due to phenotypic plasticity. Sci. Total Environ. 753, 141896. https://doi.org/10.1016/j.scitotenv.2020.141896.

Bókony, V., Üveges, B., Ujhegyi, N., Verebélyi, V., Nemesházi, E., Csíkvári, O., Hettyey, A., 2018. Endocrine disruptors in breeding ponds and reproductive health of toads in agricultural, urban and natural landscapes. Sci. Total Environ. 634, 1335-1345. https://doi.org/10.1016/j.scitotenv.2018.03.363.

Bókony, V., Verebélyi, V., Ujhegyi, N., Mikó, Z., Nemesházi, E., Szederkényi, M., Orf, S., Vitányi, E., Móricz, Á.M., 2020. Effects of two little-studied environmental pollutants on early development in anurans. Environ. Pollut. 260, 114078. https://doi.org/ 10.1016/j.envpol.2020.114078.

Brans, K.I., Engelen, J.M.T., Souffreau, C., De Meester, L., 2018. Urban hot-tubs: local urbanization has profound effects on average and extreme temperatures in ponds. Landsc. Urban Plann. 176, 22-29. https://doi.org/10.1016/j. landurbplan.2018.03.013.

Brown, A.R., Owen, S.F., Peters, J., Zhang, Y., Soffker, M., Paull, G.C., Hosken, D.J., Wahab, M.A., Tyler, C.R., 2015. Climate change and pollution speed declines in zebrafish populations. Proc. Natl. Acad. Sci. U.S.A. 112, E1237-E1246. https://doi. org/10.1073/pnas.1416269112.

Burraco, P., Orizaola, G., Monaghan, P., Metcalfe, N.B., 2020. Climate change and ageing in ectotherms. Global Change Biol. 26, 5371-5381. https://doi.org/10.1111/ gcb. 15305.

Castañeda Cortés, D.C., Padilla, L.F.A., Langlois, V.S., Somoza, G.M., Fernandino, J.I., 2019. The central nervous system acts as a transducer of stress-induced masculinization through corticotropin-releasing hormone B. Development 146, dev172866. https://doi.org/10.1242/dev.172866.

Castelli, M.A., Whiteley, S.L., Georges, A., Holleley, C.E., 2020. Cellular calcium and redox regulation: the mediator of vertebrate environmental sex determination? Biol. Rev. Camb. Phil. Soc. 95, 680-695. https://doi.org/10.1111/brv.12582.

Chardard, D., Penrad-Mobayed, M., Chesnel, A., Pieau, C., Dournon, C., 2004. Thermal sex reversals in amphibians. In: Valenzuela, N., Lance, V. (Eds.), TemperatureDependent Sex Determination in Vertebrates. Smithsonian Books, Washington, D.C, pp. 59-67.

DeCourten, B., Romney, A., Brander, S., 2019. The Heat Is on: Complexities of Aquatic Endocrine Disruption in a Changing Global Climate. In: Separation Science and Technology, first ed. Elsevier Inc, New York. https://doi.org/10.1016/B978-0-12815730-5.00002-8.

DeCourten, B.M., Brander, S.M., 2017. Combined effects of increased temperature and endocrine disrupting pollutants on sex determination, survival, and development across generations. Sci. Rep. 7, 9310. https://doi.org/10.1038/s41598-017-096311.

Dournon, C., Houillon, C., Pieau, C., 1990. Temperature sex-reversal in amphibians and reptiles. Int. J. Dev. Biol. 34, 81-92.

Eggert, C., 2004. Sex determination: the amphibian models. Reprod. Nutr. Dev. 44, 539-549. https://doi.org/10.1051/rnd:2004062.

Fainsod, A., Kot-Leibovich, H., 2018. Xenopus embryos to study fetal alcohol syndrome, a model for environmental teratogenesis. Biochem. Cell. Biol. 96, 77-87. https://doi. org/10.1139/bcb-2017-0219.

Falconi, R., Petrini, S., Quaglia, A., Zaccanti, F., 2001. Fine structure of undifferentiated gonads in Rana dalmatina tadpoles. Ital. J. Zool. 68, 15-21. https://doi.org/ 10.1080/11250000109356378.

Fernandino, J.I., Hattori, R.S., Moreno Acosta, O.D., Strüssmann, C.A., Somoza, G.M., 2013. Environmental stress-induced testis differentiation: androgen as a by-product of cortisol inactivation. Gen. Comp. Endocrinol. 192, 36-44. https://doi.org/ 10.1016/j.ygcen.2013.05.024.

Flament, S., 2016. Sex reversal in amphibians. Sex. Dev. 10, 267-278. https://doi.org/ $10.1159 / 000448797$.

Geffroy, B., Wedekind, C., 2020. Effects of global warming on sex ratios in fishes. J. Fish. Biol. 97, 596-606. https://doi.org/10.1111/jfb.14429.

Gosner, K.L., 1960. A simplified table for staging anuran embryos and larvae with notes on identification. Herpetologica 16, 183-190.

Grayson, K.L., Mitchell, N.J., Monks, J.M., Keall, S.N., Wilson, J.N., Nelson, N.J., 2014. Sex ratio bias and extinction risk in an isolated population of Tuatara (Sphenodon punctatus). PloS One 9, e94214. https://doi.org/10.1371/journal.pone.0094214.

Gyllenhammar, I., Holm, L., Eklund, R., Berg, C., 2009. Reproductive toxicity in Xenopus tropicalis after developmental exposure to environmental concentrations of ethynylestradiol. Aquat. Toxicol. 91, 171-178. https://doi.org/10.1016/j. aquatox.2008.06.019.

Hector, K.L., Bishop, P.J., Nakagawa, S., 2012. Consequences of compensatory growth in an amphibian. J. Zool. 286, 93-101. https://doi.org/10.1111/j.1469. 7998.2011.00850.x.

Hogan, N.S., Duarte, P., Wade, M.G., Lean, D.R.S., Trudeau, V.L., 2008. Estrogenic exposure affects metamorphosis and alters sex ratios in the northern leopard frog (Rana pipiens): identifying critically vulnerable periods of development. Gen. Comp. Endocrinol. 156, 515-523. https://doi.org/10.1016/j.ygcen.2008.03.011.

Holleley, C.E., Sarre, S.D., O'Meally, D., Georges, A., 2016. Sex reversal in reptiles: reproductive oddity or powerful driver of evolutionary change? Sex. Dev. 10, 279-287. https://doi.org/10.1159/000450972.

Hooper, M.J., Ankley, G.T., Cristol, D.A., Maryoung, L.A., Noyes, P.D., Pinkerton, K.E., 2013. Interactions between chemical and climate stressors: a role for mechanistic toxicology in assessing climate change risks. Environ. Toxicol. Chem. 32, 32-48. https://doi.org/10.1002/etc.2043.

Hu, Q., Tian, H., Xiao, H., 2019. Effects of temperature and sex steroids on sex ratio, growth, and growth-related gene expression in the Chinese giant salamander Andrias davidianus. Aquat. Biol. 28, 79-90. https://doi.org/10.3354/ab00710. 
IPCC, 2014. Climate Change 2014: Synthesis Report. Contribution of Working Groups I, II and III to the Fifth Assessment Report of the Intergovernmental Panel on Climate Change. IPCC, Geneva, Switzerland.

Jakab, G., Szalai, Z., Michalkó, G., Ringer, M., Filep, T., Szabó, L., Maász, G., Pirger, Z., Ferincz, Á., Staszny, Á., Dobosy, P., Kondor, A.C., 2020. Thermal baths as sources of pharmaceutical and illicit drug contamination. Environ. Sci. Pollut. Res. Int. 27, 399-410. https://doi.org/10.1007/s11356-019-06633-6.

Kaya, U., Kuzmin, S., Sparreboom, M., Ugurtas, I.H., Tarkhnishvili, D., Anderson, S., Andreone, F., Corti, C., Nyström, P., Schmidt, B., Anthony, B., Ogrodowczyk, A., Ogielska, M., Bosch, J., Tejedo, M., 2009. Rana dalmatina. IUCN red list threat. Species e.T58584A11790570. https://doi.org/10.2305/IUCN.UK.2009.RLTS. T58584A11790570.en.

Kitano, T., Hayashi, Y., Shiraishi, E., Kamei, Y., 2012. Estrogen rescues masculinization of genetically female medaka by exposure to cortisol or high temperature. Mol. Reprod. Dev. 79, 719-726. https://doi.org/10.1002/mrd.22080.

Kitano, T., Yoshinaga, N., Shiraishi, E., Koyanagi, T., Abe, S.-I., 2007. Tamoxifen induces masculinization of genetic females and regulates P450 aromatase and Müllerian inhibiting substance mRNA expression in Japanese flounder (Paralichthys olivaceus). Mol. Reprod. Dev. 74, 1171-1177. https://doi.org/10.1002/mrd.20603.

Lambert, M.R., 2015. Clover root exudate produces male-biased sex ratios and accelerates male metamorphic timing in wood frogs. R. Soc. Open Sci. 2, 150433. https://doi.org/10.1098/rsos.150433.

Lambert, M.R., Skelly, D.K., Ezaz, T., 2016. Sex-linked markers in the North American green frog (Rana clamitans) developed using DArTseq provide early insight into sex chromosome evolution. BMC Genom. 17, 844. https://doi.org/10.1186/s12864. 016-3209-x.

Lambert, M.R., Smylie, M.S., Roman, A.J., Freidenburg, L.K., Skelly, D.K., 2018. Sexual and somatic development of wood frog tadpoles along a thermal gradient. J. Exp. Zool. Part A, Ecol. Integr. Physiol. 329, 72-79. https://doi.org/10.1002/jez.2172.

Lambert, M.R., Tran, T., Kilian, A., Ezaz, T., Skelly, D.K., 2019. Molecular evidence for sex reversal in wild populations of green frogs (Rana clamitans). PeerJ 7, e6449. https://doi.org/10.7717/peerj.6449.

Lenth, R., Singmann, H., Love, J., Buerkner, P., Herve, M., 2020. Emmeans: Estimated Marginal Means, Aka Least-Squares Means.

Liker, A., Freckleton, R.P., Székely, T., 2014. Divorce and infidelity are associated with skewed adult sex ratios in birds. Curr. Biol. 24, 880-884. https://doi.org/10.1016/j. cub.2014.02.059.

Liker, A., Freckleton, R.P., Székely, T., 2013. The evolution of sex roles in birds is related to adult sex ratio. Nat. Commun. 4, 1587. https://doi.org/10.1038/ncomms2600.

Lindauer, A.L., Maier, P.A., Voyles, J., 2020. Daily fluctuating temperatures decrease growth and reproduction rate of a lethal amphibian fungal pathogen in culture. BMC Ecol. 20, 18. https://doi.org/10.1186/s12898-020-00286-7.

Liwanag, H.E.M., Haro, D., Callejas, B., Labib, G., Pauly, G.B., 2018. Thermal tolerance varies with age and sex for the nonnative Italian Wall Lizard (Podarcis siculus) in Southern California. J. Therm. Biol. 78, 263-269. https://doi.org/10.1016/j. jtherbio.2018.10.010.

Loos, R., Gawlik, B.M., Locoro, G., Rimaviciute, E., Contini, S., Bidoglio, G., 2009. EUwide survey of polar organic persistent pollutants in European river waters. Environ. Pollut. 157, 561-568. https://doi.org/10.1016/j.envpol.2008.09.020.

Mackenzie, C.A., Berrill, M., Metcalfe, C., Pauli, B.D., 2003. Gonadal differentiation in frogs exposed to estrogenic and antiestrogenic compounds. Environ. Toxicol. Chem. 22, 2466-2475. https://doi.org/10.1897/02-173.

Marques da Cunha, L., Maitre, D., Wedekind, C., 2019. Low adaptive potential for tolerance to ethynylestradiol, but also low toxicity, in a grayling population (Thymallus thymallus). BMC Evol. Biol. 19, 227. https://doi.org/10.1186/s12862019-1558-1.

Medina, M., Barata, C., Telfer, T., Baird, D.J., 2002. Age- and sex-related variation in sensitivity to the pyrethroid cypermethrin in the marine copepod Acartia tonsa Dana. Arch. Environ. Contam. Toxicol. 42, 17-22. https://doi.org/10.1007/ s002440010286.

Mina, O., Gall, H.E., Elliott, H.A., Watson, J.E., Mashtare, M.L., Langkilde, T., Harper, J. P., Boyer, E.W., 2018. Estrogen occurrence and persistence in vernal pools impacted by wastewater irrigation practices. Agric. Ecosyst. Environ. 257, 103-112. https:// doi.org/10.1016/j.agee.2018.01.022.

Mitchell, N.J., Janzen, F.J., 2010. Temperature-dependent sex determination and contemporary climate change. Sex. Dev. 4, 129-140. https://doi.org/10.1159/ 000282494.

Mizoguchi, B.A., Valenzuela, N., 2016. Ecotoxicological perspectives of sex determination. Sex. Dev. 10, 45-57. https://doi.org/10.1159/000444770.

Monaghan, P., 2008. Early growth conditions, phenotypic development and environmental change. Philos. Trans. R. Soc. Lond. B Biol. Sci. 363, 1635-1645. https://doi.org/10.1098/rstb.2007.0011.

National Center for Biotechnology Information, 2020. PubChem compound summary for CID 5991, ethinyl estradiol [WWW document]. https://pubchem.ncbi.nlm.nih. gov/compound/Ethinyl-estradiol.

Nemesházi, E., Gál, Z., Ujhegyi, N., Verebélyi, V., Mikó, Z., Üveges, B., Lefler, K.K., Jeffries, D.L., Hoffmann, O.I., Bókony, V., 2020. Novel genetic sex markers reveal high frequency of sex reversal in wild populations of the agile frog (Rana dalmatina) associated with anthropogenic land use. Mol. Ecol. 29, 3607-3621. https://doi.org/ 10.1111/mec.15596.

Nemesházi, E., Kövér, S., Bókony, V., 2021. Evolutionary and demographic consequences of temperature-induced masculinization under climate warming: the effects of mate choice. BMC Ecol. Evol. 21 (16) https://doi.org/10.1186/s12862-021-01747-3.

Noyes, P.D., Lema, S.C., 2015. Forecasting the impacts of chemical pollution and climate change interactions on the health of wildlife. Curr. Zool. 61, 669-689. https://doi. org/10.1093/czoolo/61.4.669.
Ogielska, M., Kotusz, A., 2004. Pattern and rate of ovary differentiation with reference to somatic development in anuran amphibians. J. Morphol. 259, 41-54. https://doi. org/10.1002/jmor.10162.

Orizaola, G., Laurila, A., 2009. Intraspecific variation of temperature-induced effects on metamorphosis in the pool frog (Rana lessonae). Can. J. Zool. 87, 581-588. https:// doi.org/10.1139/Z09-045.

Orton, F., Tyler, C.R., 2015. Do hormone-modulating chemicals impact on reproduction and development of wild amphibians? Biol. Rev. Camb. Phil. Soc. 90, 1100-1117. https://doi.org/10.1111/brv.12147.

Ospina-Alvarez, N., Piferrer, F., 2008. Temperature-dependent sex determination in fish revisited: prevalence, a single sex ratio response pattern, and possible effects of climate change. PloS One 3, e2837. https://doi.org/10.1371/journal.pone.0002837.

Parmesan, C., 2006. Ecological and evolutionary responses to recent climate change. Annu. Rev. Ecol. Evol. Syst. 37, 637-669. https://doi.org/10.1146/annurev. ecolsys.37.091305.110100.

Peng, Y., Kwok, K.H.H., Yang, P.-H., Ng, S.S.M., Liu, J., Wong, O.G., He, M.-L., Kung, H.F., Lin, M.C.M., 2005. Ascorbic acid inhibits ROS production, NF-kappa B activation and prevents ethanol-induced growth retardation and microencephaly. Neuropharmacology 48, 426-434. https://doi.org/10.1016/j. neuropharm.2004.10.018.

Perrin, N., 2016. Random sex determination: when developmental noise tips the sex balance. Bioessays 38, 1218-1226. https://doi.org/10.1002/bies.201600093.

Pettersson, I., Berg, C., 2007. Environmentally relevant concentrations of ethynylestradiol cause female-biased sex ratios in Xenopus tropicalis and Rana temporaria. Environ. Toxicol. Chem. 26, 1005-1009. https://doi.org/10.1897/06 464R.1.

Pike, N., 2011. Using false discovery rates for multiple comparisons in ecology and evolution: false discovery rates for multiple comparisons. Methods Ecol. Evol. 2, 278-282. https://doi.org/10.1111/j.2041-210X.2010.00061.x.

Quinn, A.E., Sarre, S.D., Ezaz, T., Marshall Graves, J.A., Georges, A., 2011. Evolutionary transitions between mechanisms of sex determination in vertebrates. Biol. Lett. 7, 443-448. https://doi.org/10.1098/rsbl.2010.1126.

R Core Team, 2020. R: A Language and Environment for Statistical Computing.

Rechsteiner, D., Wettstein, F.E., Warren, B.P., Enne, E., Vermeirssen, L.M., Simon, E., Schneider, M.K., Hollender, J., Bucheli, T.D., 2020. Natural Estrogens in Surface Waters of a Catchment with Intensive Livestock Farming in Switzerland $\dagger$ https:// doi.org/10.1039/d0em00317d.

Ruxton, G.D., Beauchamp, G., 2008. Time for some a priori thinking about post hoc testing. Behav. Ecol. 19, 690-693. https://doi.org/10.1093/beheco/arn020.

Schwanz, L.E., Cordero, G.A., Charnov, E.L., Janzen, F.J., 2016. Sex-specific survival to maturity and the evolution of environmental sex determination. Evolution (N. Y). 70, 329-341. https://doi.org/10.1111/evo.12856.

Schwanz, L.E., Georges, A., Holleley, C.E., Sarre, S.D., 2020. Climate change, sex reversal and lability of sex-determining systems. J. Evol. Biol. 33, 270-281. https://doi.org/ 10.1111/jeb.13587.

Senior, A.M., Nat Lim, J., Nakagawa, S., 2012. The fitness consequences of environmental sex reversal in fish: a quantitative review. Biol. Rev. Camb. Phil. Soc. 87, 900-911. https://doi.org/10.1111/j.1469-185X.2012.00230.x.

Sparling, D.W., Linder, G., Bishop, C.A., Krest, S.K., 2010. Ecotoxicology of Amphibians and Reptiles, second ed. CRC Press/Taylor \& Francis; SETAC, Boca Raton, Fla.

Spinoni, J., Lakatos, M., Szentimrey, T., Bihari, Z., Szalai, S., Vogt, J., Antofie, T., 2015. Heat and cold waves trends in the Carpathian Region from 1961 to 2010. Int. J. Climatol. 35, 4197-4209. https://doi.org/10.1002/joc.4279.

Squires, Z.E., Bailey, P.C.E., Reina, R.D., Wong, B.B.B.M., 2010. Compensatory growth in tadpoles after transient salinity stress. Mar. Freshw. Res. 61, 219-222. https://doi. org/10.1071/MF09123.

Stöck, M., Savary, R., Betto-Colliard, C., Biollay, S., Jourdan-Pineau, H., Perrin, N., 2013. Low rates of $\mathrm{X}-\mathrm{Y}$ recombination, not turnovers, account for homomorphic sex chromosomes in several diploid species of Palearctic green toads (Bufo viridis subgroup). J. Evol. Biol. 26, 674-682. https://doi.org/10.1111/jeb.12086.

Tamschick, S., Rozenblut-Kościsty, B., Ogielska, M., Lehmann, A., Lymberakis, P., Hoffmann, F., Lutz, I., Kloas, W., Stöck, M., 2016. Sex reversal assessments reveal different vulnerability to endocrine disruption between deeply diverged anuran lineages. Sci. Rep. 6, 23825. https://doi.org/10.1038/srep23825.

Taylor, B.E., Brundage, C.M., 2013. Chronic, but not acute, ethanol exposure impairs central hypercapnic ventilatory drive in bullfrog tadpoles. Respir. Physiol. Neurobiol. 185, 533-542. https://doi.org/10.1016/j.resp.2012.11.006.

Tomczyk, A.M., Bednorz, E., 2019. Heat waves in Central Europe and tropospheric anomalies of temperature and geopotential heights. Int. J. Climatol. 39, 4189-4205. https://doi.org/10.1002/joc.6067.

Tompsett, A.R., Wiseman, S., Higley, E., Giesy, J.P., Hecker, M., 2013. Effects of exposure to $17 \alpha$-ethynylestradiol during larval development on growth, sexual differentiation, and abundances of transcripts in the liver of the wood frog (Lithobates sylvaticus). Aquat. Toxicol. 126, 42-51. https://doi.org/10.1016/j.aquatox.2012.10.003.

Tompsett, A.R., Wiseman, S., Higley, E., Pryce, S., Chang, H., Giesy, J.P., Hecker, M., 2012. Effects of $17 \alpha$-ethynylestradiol on sexual differentiation and development of the African clawed frog (Xenopus laevis). Comp. Biochem. Physiol. Toxicol. Pharmacol. CBP 156, 202-210. https://doi.org/10.1016/j.cbpc.2012.06.002.

Ujhegyi, N., Bókony, V., 2020. Skin coloration as a possible non-invasive marker for skewed sex ratios and gonadal abnormalities in immature common toads (Bufo bufo). Ecol. Indicat. 113, 106175. https://doi.org/10.1016/j.ecolind.2020.106175.

Wedekind, C., 2017. Demographic and genetic consequences of disturbed sex determination. Philos. Trans. R. Soc. Lond. B Biol. Sci. 372 https://doi.org/10.1098/ rstb.2016.0326.

Whitney, J.E., Al-Chokhachy, R., Bunnell, D.B., Caldwell, C.A., Cooke, S.J., Eliason, E.J., Rogers, M., Lynch, A.J., Paukert, C.P., 2016. Physiological basis of climate change 
impacts on North American inland fishes. Fisheries 41, 332-345. https://doi.org/ $10.1080 / 03632415.2016 .1186656$. 